\title{
IMPROVEMENT IN ANAEROBIC GERMINATION POTENTIAL AND GRAIN YIELD OF RICE (ORYZA SATIVA) THROUGH SEED PRIMING
}

\author{
S. Senapati, S.R. Kuanar and R.K. Sarkar* \\ Department of Crop Physiology and Biochemistry \\ ICAR-National Rice Research Institute, Cuttack-753 006, India
}

\begin{abstract}
A field experiment was conducted during the dry season of 2014 and 2015 at National Rice Research Institute (NRRI), Orissa, India, $\left(20.5^{\circ} \mathrm{N}\right.$, $86^{\circ} \mathrm{E}$, and 23.5 meters above mean sea level). Seed priming was employed to enhance the anaerobic germination potential in two near isogenic rice lines (IR64 and IR64-Sub1). Under natural field condition, oxygen concentration in floodwater never dropped to zero. It varied from 3.0 to $5.2 \mathrm{mg} \mathrm{L}^{-1}$. Seed priming with calcium peroxide and seed soaking with water followed by sun drying showed greater beneficial effects as compared to potassium nitrate. Seed priming with sodium peroxide found deleterious. Cultivar IR64-Sub1 responded well due to seed priming as compared to cultivar IR64 under submergence. To improve anaerobic germination potential in rice, seed soaking with water followed by sun drying found economicalas compared to other methods of seed priming as this technique was not linked with additional investment in chemicals and was more environments friendly.
\end{abstract}

Keywords: Germination, Oxygen Deficiency Tolerance, Plant Stand, Rice, Seed Priming

\section{INTRODUCTION}

Rice is grown at different ecosystems starting from rainfed lowland flood prone to aerobic to irrigate ecology. Under irrigate ecology, transplanting is the main means of rice cultivation whereas under aerobic condition, direct seeding is the only way. Under rainfed lowland, both direct seeding and transplanting methods are followed. Direct seeding reduces the cost of cultivation under irrigated condition whereas in addition of reduction of cost of cultivation in rainfed lowland, it imparts robustness in seedlings enabling them to withstand complete submergence during flooding (Sarkar, 1998). Direct seeding has several advantages, yet it needs a paradigm shift in the process of cultivation to realize the full potential of the method (Mamun, 2014).

\footnotetext{
*Corresponding Author: rksarkarcrri@gmail.com
} 
Greater weeds menace, germination failure due to stagnation of water on soil surface vis-à-vis improper plant stand are some of the concern to adapt direct seeding practice of rice cultivation. Sowing of seeds on the surface of soil surface is too risky compared to seed sown below the soil surface. Problem of direct seeding is greatly decreased if anaerobic seeding is practiced (Ray et al., 2016). In this process, seeds are sown below soil surface and shallow soil flooding with $5-10 \mathrm{~cm}$ is imposed. Under such condition, the growth of plumule is minimal while the growth of radicle is severely inhibited. Most of the rice varieties fail to establish due to lack of oxygen near seeds (Vijayan et al., 2018).Improving germination potential of rice under Oxygen deficiency can alleviate the flooding stress at early emergence stage.

Submergence tolerant gene / QTL - 'SUBI' has been introduced in several mega rice varieties. SUB1 imparts tolerance to complete submergence. Importantly, these introgression lines can also replace some of the low-yielding traditional landraces currently being used by farmers in submergence-prone areas, augmenting yields in typically marginalized fields. Farmers are now greatly adopting the rice cultivar possessing SUB1 (Dar et al., 2013). It was observed that cultivars with SUB1 failed measurably at farmer's field under direct seeding condition due to untimely rain at germination stage. Stagnation of 5-10 cm of water on the surface of the field for 10 days or more severely restricted the establishment (Das et al., 2004; Ismail et al., 2009). Seed priming, an old age practice, was applied to improve the germination capacity in rice to encounter the abiotic stresses (Farooq et al., 2011; Sarkar, 2012). Therefore, in the present investigation, an attempt has been made to assess the effectiveness of seed priming and seed coating in improving germination potential of rice under submerge condition with two near isogenic lines IR64 and IR64-Sub1 in relation to yield and yield attributing parameters under direct sown field condition.

\section{MATERIALS AND METHODS}

\section{Plant materials and growth condition}

Two near isogenic rice (Oryza sativa L.) cultivars i.e. IR64, susceptible to complete submergence and IR64-Sub1, tolerant to complete submergence, were used to investigate the effects of seed priming on seed germination and yield under early flooding and non-flooding conditions. The experiment was conducted during the dry season of 2014 and 2015 at National Rice Research Institute (NRRI), Orissa, India, $\left(20.5^{\circ} \mathrm{N}, 86^{\circ} \mathrm{E}\right.$, and 23.5 meters above mean sea level).

\section{Seed priming with water}

Seeds were soaked in tap water for 17 hours at room temperature $\left(25-33^{\circ} \mathrm{C}\right)$ in dark (16:00-09:00 h). The soaked seeds were spread on a concrete floor and dried under the Sun till the moisture content reached $10-12 \%$. The dried seeds were kept in plastic bags under normal ambient condition. The seed lot was prepared 10 days before sowing. 


\section{Seed coating with different chemicals}

Seed coating were done with calcium peroxide (65\%, HIMEDIA, India), potassium nitrate (99\%, HIMEDIA, India) and sodium peroxide (78\%, HIMEDIA, India). One hundred gram of each chemical was properly mixed with four hundred gram of dried fine farm soil. $500 \mathrm{gm}$ of mixture was used to coat one $\mathrm{kg}$ of paddy. The seeds were treated with the specific chemical and farm soil mixture by simultaneous shaking and spraying with water mist in a tray. Stirring and spraying continued until all the powder was attached to the seed. Coated seed were kept at room temperature (27$\left.31^{\circ} \mathrm{C}\right)$ to dry and harden the coat. The duration from pelleting to seeding was 20 hours.

\section{Experiment-I during the year 2014 dry season}

The primed and non-primed seeds were directly sown beneath $(1-2 \mathrm{~cm})$ the puddled soil surface in an experimental field tank ( $\mathrm{L} \times \mathrm{B} \times \mathrm{H}=40 \mathrm{~m} \times 8 \mathrm{~m} \times 0.8 \mathrm{~m})$. Field bunds approximately $15 \mathrm{~cm}$ in height from soil surface were raised with mud. Seed (4 -5 in numbers) were sown $15 \mathrm{~cm}$ apart in each line. Line to line distance was $20 \mathrm{~cm}$. The experiment was conducted under factorial randomised block design with three replications. Flooding was done after sowing with $10 \mathrm{~cm}$ depth of water, which was continuedtill 20 days of sowing. There was no stagnation of water in control plot. Similar water level $(0-10 \mathrm{~cm})$ was maintained in all plots after 21 days of sowing. Chemical fertilizers were added @ 80:40:40 NPK kg ha ${ }^{-1}$. All P and 2/3 K were applied as basal dose before sowing. Nitrogen was added in 3 splits as basal (1/2 part) and at 30 (1/4 part) and 60 (1/4 part) days after sowing. Rest amount of $\mathrm{K}$ was applied along with $\mathrm{N}$ after 60 days of sowing. Weeding was done once after 35 days of sowing.

\section{Experiment-II during the year 2015 dry season}

The experiment was conducted under bigger field condition. Mud bund was raised to provide the desired level of flooding during germination stage. Seeing the performances of each treatment in the previous year, three seed treatments such as non-priming and priming with water were taken. Crops were raised under direct seeding with and without soil flooding and under transplanting. Two seedlings were sown $15 \mathrm{~cm}$ apart in each line. The distance between lines was $20 \mathrm{~cm}$. All other operations were similar as described in experiment I.

\section{Flood water characterisites}

Temperature and oxygen concentration of flood water were determined at 07:00 hrs (model Simplair-F-5, Syland Scientific, Heppenheim, Germany). A portable $\mathrm{pH}$ meter was used to determine the $\mathrm{pH}$ of the flood-water.

\section{Plant establishment, growth and yield parameters}

Emergence of leaf tips were noted regularly after 3 days of submergence up to 21 days of sowing. Considering final emergence as $100 \%$ days to emergence was 
calculated. Under submergence, $100 \%$ emergence occurred within 9-15 days of sowing whereas under control, the emergence time was 3-4 days. Final stand (\%) was calculated as;

$$
\text { Final Stand }=\frac{\text { Number of hills with plant }}{\text { Total number of hills }} \times 100
$$

Hill with at least one seedling was considered as hill with plant. To determine the seedling length and dry matter accumulation, ten plants was randomly harvested from different hills after 21 days ofsowing. Five hills were taken at flowering stage whereas twenty hills were taken at harvest to determine different growth and yield attributing parameters. Data on leaf mass:leaf area ratio, leaf, stem and panicle dry mass was taken at flowering. The harvested sample was oven dried at $65 \pm 2^{0} \mathrm{C}$ for 72 $\mathrm{h}$ to determine dry mass. Harvest index (\%) was calculated as;

$$
\text { Harvest Index }=\frac{\text { Grain Yield }}{\text { Biological Yield }} \times 100
$$

Data on yield were taken on per plot basis and then converted into $\mathrm{tha}^{-1}$.

\section{Statistical analysis}

Differences between different treatments were compared using CropStat (International Rice Research Institute, Philippines) software's least significant difference (LSD, $p<0.05)$.

\section{RESULTS}

\section{EXPERIMENT-I DURING THE YEAR 2014 DRY SEASON}

\section{Flood-water characteristics}

The temperature of floodwater ranged from 27.5 to $29.2^{\circ} \mathrm{C}$ throughout the period of the experiment (Fig. 1). The concentration of Oxygen was $3.0 \mathrm{mg} \mathrm{L}^{-1}$ just after 1 day of submergence whereas it increased gradually and after 15 days of submergence, the concentration Oxygen of floodwater was $5.2 \mathrm{mg} \mathrm{L}^{-1}$. There was an upward trend of $\mathrm{pH}$ of floodwater. After one day of submergence, the $\mathrm{pH}$ of the floodwater was 7.8, which became 8.2 after 15 days of submergence.

\section{Emergence, plant stand and seedling growth}

Flooding at germination stage had negative impact on plant establishment (Fig. 2A). Seed priming with sodium peroxide ( $\mathrm{P} 3$ ) showed greater negative effect as compared to non-primed seed (P1). Days to $100 \%$ emergence was more in P3 followed by P1, P4 (potassium nitrate coating) and P2 (calcium peroxide coating) and P5 (water priming with soaking and drying). Plant stand was significantly greater under submergence in P2 and P5 followed by P4, P1 and P3 (Fig. 2B). The performances of cultivar in respect of plant establishment were significantly better in cultivar with IR64-Sub1 as compared to the cultivar IR64. Plant establishment was 87\%, 84\% and $68 \%$ in IR64-Sub1 under P2, P5 and P4 treatment whereas in IR64, it was 68\%, $73 \%$ and $61 \%$, respectively. 


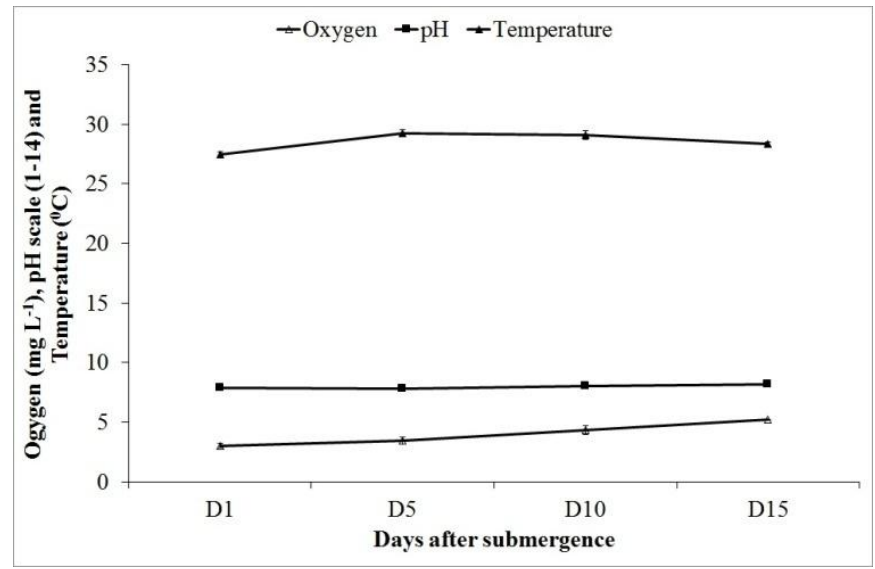

Figure 1. Concentrations of oxygen, temperature and $\mathrm{pH}$ of flood water at different days of submergence. D1, D5, D10 and D15 represent 1, 5, 10 and 15 days after sowing. Bar represents standard deviation.

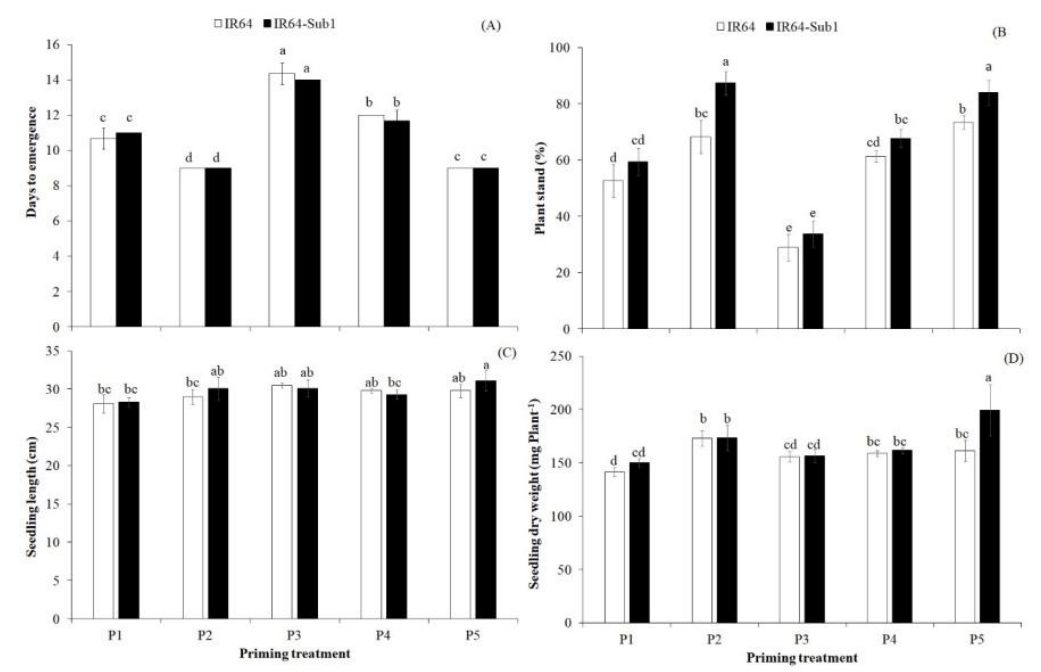

Figure 2. (A)Days to $100 \%$ emergence of coleoptiles tip above the water surface. (B) Final plant stands (\%) after 21 days of submergence. (C) Seedling length and (D) dry mass of nonprimed and primed seed under submergence after 21 days of sowing [P1 = control, nonprimed; $\mathrm{P} 2$ = calcium peroxide coated; $\mathrm{P} 3$ = sodium peroxide coated; $\mathrm{P} 4$ = potassium nitrate coated; P5 = seed soaking with water followed by sun drying]. Bar represents standard deviation. The same small case did not differ significantly.

Seed priming increased both seedling length and dry matter accumulation (Fig. 2C, 2D). Cultivar differences in seedling length were non-significant. The seedlings emerged out from the water surface grew well and attained the length more than 25 
$\mathrm{cm}$ in all the treatments. Cultivar with IR64-Sub1 accumulated greater amount of dry matter under various seed priming treatments as compared to cultivar IR64. Cultivar differences in dry matter accumulation were highly significant. Both cultivar and seed priming treatments together influenced the dry matter accumulation at early stage of plant growth.

\section{Seed priming and its impact on biomass accumulation at flowering}

Dry mass differed greatly at flowering stage (Table 1). Leaf mass and leaf area ratio greatly influenced by seed priming. The differences due to cultivar were nonsignificant. Leaf and stem dry mass at flowering were significantly greater in IR64Sub1 as compared to IR64. Biomass accumulation was significantly greater in P2 and P5 as compared to non-priming and other seed priming treatments. Seed priming with sodium peroxide (P3) negatively influenced the dry matter accumulation. Cultivar and seed priming interaction significantly changed the stem and panicle dry mass accumulation at flowering.

Table 1. Seed priming and its impact on dry matter production at flowering stage during the year 2014 dry season

\begin{tabular}{|c|c|c|c|c|c|}
\hline Cultivar & Treatment & $\begin{array}{c}\text { Leaf mass: } \\
\text { leaf area } \\
\text { ratio }\end{array}$ & $\begin{array}{c}\text { Leaf dry } \\
\text { mass }\left(\mathrm{g} \mathrm{m}^{-2}\right)\end{array}$ & $\begin{array}{l}\text { Stem dry } \\
\text { mass } \\
\left(\mathrm{g} \mathrm{m}^{-2}\right)\end{array}$ & $\begin{array}{l}\text { Panicle dry } \\
\text { mass }\left(\mathrm{g} \mathrm{m}^{-2}\right)\end{array}$ \\
\hline \multirow[t]{5}{*}{ IR64 } & $\mathrm{P} 1$ & $6.66^{\mathrm{b}}$ & $91.3^{\mathrm{e}}$ & $191.0^{\mathrm{e}}$ & $60.2^{\mathrm{e}}$ \\
\hline & $\mathrm{P} 2$ & $6.25^{\mathrm{c}}$ & $116.9^{\mathrm{d}}$ & $279.4^{\mathrm{c}}$ & $74.0^{\mathrm{c}}$ \\
\hline & $\mathrm{P} 3$ & $7.43^{\mathrm{a}}$ & $74.3^{\mathrm{f}}$ & $176.5^{\mathrm{ef}}$ & $48.2^{\mathrm{f}}$ \\
\hline & P4 & $6.67^{\mathrm{b}}$ & $112.9^{\mathrm{d}}$ & $276.6^{\mathrm{c}}$ & $64.7^{\mathrm{d}}$ \\
\hline & P5 & $6.22^{\mathrm{c}}$ & $137.6^{\mathrm{bc}}$ & $307.4^{\mathrm{b}}$ & $73.9^{\mathrm{c}}$ \\
\hline \multicolumn{2}{|c|}{ Mean } & $6.65^{A}$ & $106.6^{B}$ & $246.2^{B}$ & $64.2^{A}$ \\
\hline \multirow[t]{5}{*}{ IR64-Sub1 } & $\mathrm{P} 1$ & $7.17^{\mathrm{a}}$ & $94.7^{\mathrm{e}}$ & $237.7^{\mathrm{d}}$ & $48.7^{\mathrm{f}}$ \\
\hline & $\mathrm{P} 2$ & $6.10^{\mathrm{c}}$ & $150.0^{\mathrm{ab}}$ & $378.1^{\mathrm{a}}$ & $95.0^{\mathrm{a}}$ \\
\hline & P3 & $7.31^{\mathrm{a}}$ & $70.9^{\mathrm{f}}$ & $170.1^{\mathrm{f}}$ & $40.7^{\mathrm{e}}$ \\
\hline & P4 & $6.41^{\mathrm{bc}}$ & $127.6^{\mathrm{cd}}$ & $301.8^{\mathrm{b}}$ & $70.5^{\mathrm{cd}}$ \\
\hline & P5 & $6.40^{\mathrm{bc}}$ & $157.7^{\mathrm{a}}$ & $367.2^{\mathrm{a}}$ & $85.6^{\mathrm{b}}$ \\
\hline \multicolumn{2}{|c|}{ Mean } & $6.68^{A}$ & $120.2^{A}$ & $290.9^{A}$ & $68.1^{A}$ \\
\hline
\end{tabular}

P1, control, non-treated; P2, calcium peroxide coated; P3, sodium peroxide coated; P4, potassium nitrate treated; P5, seed soaking with water followed by sun drying. NS, non-significant; In a column the same small and upper-case letter do not differ significantly. 


\section{Yield and yield attributes}

Seed priming differently influenced the grain yield. Seed priming treatment P2 (calcium peroxide coating) and P5 (water priming with soaking and drying) had greater positive effect whereas seed priming treatment P3 (Seed priming with sodium peroxide) had negative effect (Table 1). Grain yield production was significantly higher in P2 and P5 as compared to other priming and non-priming treatments both under control and germination stage submergence. Seed coating with potassium nitrate (P4) had neither negative nor positive effect on yield. Submergence at germination stage decreased the panicle numbers; however, the reduction was checked in P2 and P5. Yield attributing parameters such as panicle numbers per unit of land and harvest index significantly improved in P2 and P5.

\section{Experiment I during the year 2015 dry season}

Plant height was significantly greater under transplanting as compared to direct seeding, yet numbers of panicle per unit leaf area was less under transplanting as compared to direct seeding (Table 3). Single panicle weight was, however, higher under transplanting as compared to direct seeding. Fertile spikelet (\%) and harvest index did not change statistically under priming and different methods of crop raising. Seed priming improved the straw and grain yield both under transplanting and direct seeding compared with non-priming conditions and checked the yield reduction under germination stage submergence.

\section{DISCUSSION}

Direct seeding is crucial during both wet season in coastal deltas as well as in rainfed lowland areas because of lower cost and additional benefits, improve drought and submergence tolerance and earlier harvests (Sarkar and Das, 2003). Direct seeding is now facing innumerable problems due to irregular and unpredictable rainfall and climate change. Rainfall is now more uncertain with more frequencies of extreme events (Ismail et al., 2009). It is known that shallow flooding suppresses weed growth. Yet, the knowledge is not in practice due to poor germination and failure of plant establishment of rice under such condition. Sowing of seeds beneath the flooded surface was termed as anaerobic seeding (Yamauchi and Choung, 1995). Cultivar tolerant to oxygen deficiency at germination stage is successful in such situation (Ray et al., 2016; Vijayan et al., 2018). The level of oxygen of flood water varied between 3.0 and $5.2 \mathrm{mg} \mathrm{L}^{-1}$ after 1 day of submergence to 15 days after submergence (Fig. 1). It showed that flood water was always hypoxic, neither anoxic nor normoxic (Setter et al., 1995). Once the coleoptiles reached the water zone, it started to get oxygen from the surrounding floodwater and started to grow fast and pushed the tip of the coleoptile above the water surface. The $\mathrm{pH}$ and the temperature were not so harsh, which could restrict coleoptiles growth (Fig. 1). Seed coating with calcium peroxide $(\mathrm{P} 2)$ and water priming with soaking and drying treatment (P5) enabled the seedlings to pierce through water early as against non-priming and other 
treatments (Fig. 2A). Sodium peroxide (P3) coating extended date of emergence as well as final plant stand (Fig. 2B).The negative effect was noticed in respect seedling vigour (Fig. 2D). Dry matter accumulation was significantly better under P2 and P5 than other treatments. No such trend was observed with respect to seedling length (Fig. 2C). Sodium peroxide $\left(\mathrm{Na}_{2} \mathrm{O}_{2}\right)$ upon contact with water produces $\mathrm{NaOH}$ and $\mathrm{H}_{2} \mathrm{O}_{2}$, which might destroy the germinating embryo and thereby action of $\mathrm{Na}_{2} \mathrm{O}_{2}$ found to be negative. Potassium nitrate $\left(\mathrm{KNO}_{3}\right)$, which has soil oxidizing power but does not generated oxygen by itself was not so effective in cutting the emergence time and improving the plant stand. Soaking of seeds at around $30^{\circ} \mathrm{C}$ for 17 hours initiated the germination process. Enzymes associated with germination process were synthesized during imbibitions (Sarkar, 2012). When such seeds are dried upon, the metabolites / enzymes needed for germination go for hibernation (Farooq et al., 2011). While re-moisturizing of such seeds (P5), the germination process became fast. In a less span of time, seedlings pierced the soil surface and entered flood water environment. Upon reach on the water zone, coleoptiles got needed oxygen from the flooded water and continued to grow (Sarkar, 2012). Each seed priming agent except sodium peroxide impacted favourably. The order of effect was $\mathrm{P} 1<\mathrm{P} 4<\mathrm{P} 2=\mathrm{P} 5$.

Submergence at germination stage greatly influenced the biomass accumulation even at flowering stage per unit land area. Dry biomass at flowering was significantly greater in IR64-Sub1 than that of IR64 (Table 1). Sarkar (2012) reported that Swarna-Sub1 was able to accumulate greater biomass as compared to Swarna under direct sown submerge conditions. There was no significant difference of leaf mass/leaf area ratio between these two cultivars. Seed coating with $\mathrm{Na}_{2} \mathrm{O}_{2}$ though improved the leaf mass and leaf area ratio, yet it failed to produce enough biomass per unit area at flowering. The two cultivars such as IR64 and IR64-Sub1 are nearisogenic lines (NILs). Panda and Sarkar (2012) reported that NILs were identical in terms of growth and yield under stress free environment. The differences in biomass accumulation per unit land area were due to greater plant number per unit land in IR64-Sub1 compared to IR64 (Fig. 2B). The seed priming treatments improved the biomass accumulation at flowering showed positive effect on grain yield production at harvest (Table 2). Maintaining greater plant stand under different abiotic stresses is an uphill task to get maximum return from a unit of land, where plant stand decreased, the values of yield and yield attributing parameters perturbed. Plant stand decreased tremendously under P3. Due to poor plant stand, individual plant got more space to grow and became stout. Under P3 plant growth per hill basis was greater at flowering as well at harvest (data not provided) whereas per unit land basis was less (Table 1,2). 
Table 2. Seed priming and its impact on yield and yield attributes during the year 2014 dry season

\begin{tabular}{|c|c|c|c|c|c|c|c|c|c|c|c|c|c|}
\hline \multirow[t]{2}{*}{ Variety } & \multirow[t]{2}{*}{ Treatment } & \multicolumn{2}{|c|}{$\begin{array}{l}\text { Grain yield } \\
\quad\left(\text { tha }^{-1}\right)\end{array}$} & \multicolumn{2}{|c|}{$\begin{array}{l}\text { Single panicle } \\
\text { weight }(\mathrm{g})\end{array}$} & \multicolumn{2}{|c|}{$\begin{array}{c}\text { Panicle } \\
\left(\text { number } \mathrm{m}^{-2}\right)\end{array}$} & \multicolumn{2}{|c|}{$\begin{array}{c}\text { Fertile } \\
\text { spikelet } \\
(\%)\end{array}$} & \multicolumn{2}{|c|}{$\begin{array}{l}\text { Straw } \\
\left(\mathrm{t} \mathrm{ha}^{-1}\right)\end{array}$} & \multicolumn{2}{|c|}{ Harvest Index } \\
\hline & & $\mathrm{C}$ & AG & $\mathrm{C}$ & AG & $\mathrm{C}$ & $\mathrm{AG}$ & $\mathrm{C}$ & AG & $\mathrm{C}$ & $\mathrm{AG}$ & $\mathrm{C}$ & $\mathrm{AG}$ \\
\hline \multirow[t]{5}{*}{ IR64 } & $\mathrm{P} 1$ & $3.53^{\mathrm{bA}}$ & $2.39^{\mathrm{dB}}$ & $1.47^{\mathrm{bA}}$ & $1.23^{\mathrm{abcB}}$ & $309^{\mathrm{abA}}$ & $245^{\mathrm{eB}}$ & $72^{\text {abcA }}$ & $73^{\text {abcA }}$ & $5.31^{\mathrm{abA}}$ & $3.09^{\mathrm{cB}}$ & $0.40^{\mathrm{abA}}$ & $0.41^{\mathrm{abcA}}$ \\
\hline & $\mathrm{P} 2$ & $3.88^{\mathrm{aA}}$ & $3.28^{\mathrm{bB}}$ & $1.55^{\mathrm{abA}}$ & $1.21^{\mathrm{abcB}}$ & $321^{\mathrm{aA}}$ & $333^{\text {bcA }}$ & $76^{\mathrm{aA}}$ & $73^{\mathrm{abcA}}$ & $5.08^{\mathrm{abA}}$ & $4.31^{\mathrm{bB}}$ & $0.43^{\mathrm{abA}}$ & $0.43^{\mathrm{aA}}$ \\
\hline & P3 & $2.83^{\mathrm{cdA}}$ & $1.36^{\mathrm{eB}}$ & $1.37^{\mathrm{cA}}$ & $1.22^{\mathrm{abcB}}$ & $275^{\mathrm{bcdA}}$ & $138^{\mathrm{fB}}$ & $72^{\mathrm{abcA}}$ & $64^{\mathrm{dB}}$ & $4.25^{\mathrm{bcA}}$ & $2.16^{\mathrm{dB}}$ & $0.40^{\mathrm{abA}}$ & $0.37^{\mathrm{bcA}}$ \\
\hline & P4 & $3.41^{\mathrm{bcA}}$ & $2.36^{\mathrm{cB}}$ & $1.48^{\mathrm{bcA}}$ & $1.19^{\mathrm{abcB}}$ & $295^{\mathrm{abcA}}$ & $293^{\mathrm{cdA}}$ & $72^{\mathrm{abcA}}$ & $69^{\mathrm{bcA}}$ & $5.12^{\mathrm{abA}}$ & $4.01^{\mathrm{bB}}$ & $0.40^{\mathrm{abA}}$ & $0.38^{\mathrm{bcA}}$ \\
\hline & P5 & $3.80^{\mathrm{abA}}$ & $3.08^{\mathrm{bB}}$ & $1.56^{\mathrm{abA}}$ & $1.26^{\mathrm{abcB}}$ & $324^{\mathrm{aA}}$ & $341^{\text {bcA }}$ & $71^{\mathrm{bcA}}$ & $73^{\mathrm{abcA}}$ & $5.04^{\mathrm{abA}}$ & $3.84^{\mathrm{bB}}$ & $0.43^{\mathrm{abB}}$ & $0.44^{\mathrm{aA}}$ \\
\hline \multirow[t]{5}{*}{ IR64-Sub1 } & P1 & $3.45^{\mathrm{bA}}$ & $2.55^{\mathrm{cdB}}$ & $1.48^{\mathrm{bcA}}$ & $1.16^{\mathrm{bcB}}$ & $304^{\mathrm{abB}}$ & $340^{\text {bcA }}$ & $73^{\mathrm{abcA}}$ & $71^{\mathrm{bcA}}$ & $5.48^{\mathrm{abcA}}$ & $4.30^{\mathrm{bB}}$ & $0.39^{\mathrm{bA}}$ & $0.37^{\mathrm{bcA}}$ \\
\hline & $\mathrm{P} 2$ & $3.85^{\mathrm{aA}}$ & $3.65^{\mathrm{aA}}$ & $1.58^{\mathrm{abA}}$ & $1.29^{\mathrm{aB}}$ & $322^{\mathrm{aA}}$ & $345^{\text {bcA }}$ & $72^{\mathrm{abcA}}$ & $76^{\mathrm{aA}}$ & $5.18^{\mathrm{abA}}$ & $4.97^{\mathrm{aA}}$ & $0.43^{\mathrm{abA}}$ & $0.43^{\mathrm{aA}}$ \\
\hline & P3 & $2.58^{\mathrm{dA}}$ & $1.44^{\mathrm{eB}}$ & $1.38^{\mathrm{bcA}}$ & $1.27^{\mathrm{abA}}$ & $257^{\mathrm{bcdA}}$ & $161^{\mathrm{fB}}$ & $70^{\mathrm{bcA}}$ & $62^{\mathrm{dB}}$ & $4.16^{\mathrm{cA}}$ & $2.49^{\mathrm{dB}}$ & $0.38^{\mathrm{bA}}$ & $0.37^{\mathrm{bA}}$ \\
\hline & $\mathrm{P} 4$ & $3.12^{\mathrm{cA}}$ & $2.75^{\mathrm{cB}}$ & $1.49^{\mathrm{bA}}$ & $1.15^{\mathrm{bcB}}$ & $285^{\mathrm{bcdB}}$ & $319^{\mathrm{cdA}}$ & $75^{\mathrm{abA}}$ & $72^{\mathrm{abcA}}$ & $4.61^{\mathrm{bcA}}$ & $4.06^{\mathrm{bA}}$ & $0.40^{\mathrm{abA}}$ & $0.40^{\mathrm{abcA}}$ \\
\hline & P5 & $3.77^{\mathrm{abA}}$ & $3.55^{\mathrm{abB}}$ & $1.61^{\mathrm{aA}}$ & $1.17^{\mathrm{bcB}}$ & $321^{\mathrm{aB}}$ & $393^{\mathrm{aA}}$ & $76^{\mathrm{aA}}$ & $73^{\mathrm{abcA}}$ & $4.80^{\mathrm{bA}}$ & $4.59^{\mathrm{abA}}$ & $0.44^{\mathrm{aA}}$ & $0.41^{\mathrm{abcA}}$ \\
\hline
\end{tabular}

$\mathrm{P} 1$, control, non-treated; $\mathrm{P}$ 2, calcium peroxide coated; $\mathrm{P}$ 3, sodium peroxide coated; $\mathrm{P}$ 4, potassium nitrate treated; P5, seed soaking with water followed by sun drying. NS, non-significant; In a specific treatment genotypes followed by the same small case letter and across the treatment within the same genotype and treatment followed by the same upper-case letter for an individual parameter do not differ significantly

However, it was not enough to compensate the optimum plant stand to produce greater yield under a piece of land (Sarkar et al., 1999; Sarkar and Das, 2003). Seeing the performances of the year 2014, the experiment was changed. Only seed priming treatment, soaking followed by drying was employed (Plate 1).

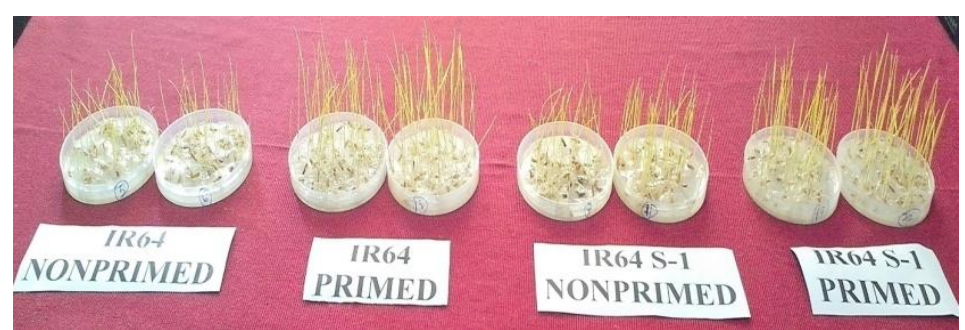

Plate 1. Growth of seedlings of two rice cultivars such as IR64 and IR64-Sub1 due to water priming.

Coating of seeds with calcium peroxide is costly. Calcium peroxide coating though known to improve germination percentage for long period, the technology is still in confined to Japan due to cost and trouble in making coated seeds. Besides, the soaking and drying treatment gave similar benefit with that of calcium peroxide coating. As rice is also cultivated through transplanting mode, a new treatment i.e. transplanting was introduced to verify the water priming efficiency in improving the 
yield under normal and anaerobic direct seeding and transplanting mode of rice cultivation. In general, there was no significant difference in yield under direct normal seeding and transplanting (Table 3). A compensatory mechanism was observed between panicle number per unit area and single panicle weight. Under normal direct seeding condition, panicle numbers were more whereas under transplanting weight of single panicle was greater. This is in conformity with our earlier findings (Sarkar and Das, 2003). Water seed priming had positive effect on yield. Yield was greater due to priming both under direct seeding and transplanting conditions (Farooq et al., 2009). Submergence at germination stage greatly decreased the yield. Yield attributing parameters such as panicle numbers, panicle weight and biomass production significantly decreased due to submergence at germination stage. Seed priming alleviated the stress and thus improved the yield contributing parameters as well as yield. The data showed that water seed priming produced similar yield in all the situations such as normal and anaerobic direct seeding as well as transplanting mode of cultivation (Table 3 ).

Table 3. Yield and yield attributes due to seed priming under different methods crop raising during the 2015 dry season

\begin{tabular}{|c|c|c|c|c|c|c|c|c|}
\hline Variety & Treatment & $\begin{array}{c}\text { Height } \\
(\mathrm{cm})\end{array}$ & $\begin{array}{c}\text { Panicle } \\
\left(\mathrm{m}^{-2}\right)\end{array}$ & $\begin{array}{c}\text { Single } \\
\text { panicle } \\
\text { weight }(\mathrm{g})\end{array}$ & $\begin{array}{c}\text { Fertile } \\
\text { spikelet }(\%)\end{array}$ & $\begin{array}{c}\text { Harvest } \\
\text { Index } \\
(\%)\end{array}$ & $\begin{array}{l}\text { Straw } \\
\left(\mathrm{t} \mathrm{ha}^{-1}\right)\end{array}$ & $\begin{array}{c}\text { Grain } \\
\text { yield } \\
\left(\mathrm{t} \mathrm{ha}^{-1}\right)\end{array}$ \\
\hline IR64 & NP-DS & $81.6^{\mathrm{cd}}$ & $282^{\mathrm{bc}}$ & $1.10^{\mathrm{c}}$ & $83.8^{\mathrm{NS}}$ & $46^{\mathrm{NS}}$ & $3.17^{\mathrm{cd}}$ & $2.68^{\mathrm{cd}}$ \\
\hline IR64 & NP-DSS & $81.4^{\mathrm{cd}}$ & $275^{\mathrm{cd}}$ & $0.99^{c}$ & $82.6^{\mathrm{NS}}$ & $45^{\mathrm{NS}}$ & $2.61^{\mathrm{e}}$ & $2.12^{\mathrm{e}}$ \\
\hline IR64 & NP-TP & $92.9^{\mathrm{b}}$ & $218^{\mathrm{e}}$ & $1.53^{\mathrm{ab}}$ & $82.5^{\mathrm{NS}}$ & $46^{\mathrm{NS}}$ & $3.33^{\mathrm{abc}}$ & $2.84^{\mathrm{b}}$ \\
\hline IR64 & P-DS & $80.4^{\mathrm{d}}$ & $347^{\mathrm{a}}$ & $1.01^{\mathrm{c}}$ & $81.7^{\mathrm{NS}}$ & $48^{\mathrm{NS}}$ & $3.54^{\mathrm{a}}$ & $3.02^{\mathrm{a}}$ \\
\hline IR64 & P-DSS & $84.8^{\mathrm{c}}$ & $347^{\mathrm{a}}$ & $1.03^{\mathrm{c}}$ & $81.9^{\mathrm{NS}}$ & $46^{\mathrm{NS}}$ & $3.43^{\mathrm{ab}}$ & $2.90^{\mathrm{ab}}$ \\
\hline IR64 & P-TP & $96.7^{\mathrm{a}}$ & $233^{\mathrm{e}}$ & $1.61^{\mathrm{a}}$ & $84.3^{\mathrm{NS}}$ & $46^{\mathrm{aNS}}$ & $3.49^{\mathrm{ab}}$ & $2.95^{\mathrm{ab}}$ \\
\hline \multicolumn{2}{|r|}{ Mean } & $86.3^{A}$ & $284^{\mathrm{A}}$ & $1.21^{\mathrm{A}}$ & $82.8^{A}$ & $0.46^{\mathrm{A}}$ & $3.26^{A}$ & $2.75^{A}$ \\
\hline IR64-Sub1 & NP-DS & $79.6^{\mathrm{d}}$ & $279^{\mathrm{cd}}$ & $0.97^{\mathrm{c}}$ & $81.4^{\mathrm{NS}}$ & $46^{\mathrm{NS}}$ & $3.08^{d}$ & $2.59^{\mathrm{d}}$ \\
\hline IR64-Sub1 & NP-DSS & $78.6^{\mathrm{d}}$ & $247^{\mathrm{d}}$ & $0.96^{\mathrm{c}}$ & $85.4^{\mathrm{NS}}$ & $42^{\mathrm{NS}}$ & $2.75^{\mathrm{e}}$ & $2.02^{\mathrm{e}}$ \\
\hline IR64-Sub1 & NP-TP & $93.5^{\mathrm{ab}}$ & $212^{\mathrm{e}}$ & $1.63^{\mathrm{a}}$ & $84.0^{\mathrm{NS}}$ & $46^{\mathrm{NS}}$ & $3.36^{\mathrm{abc}}$ & $2.58^{\mathrm{d}}$ \\
\hline IR64-Sub1 & P-DS & $80.8^{\mathrm{d}}$ & $321^{\mathrm{a}}$ & $1.01^{\mathrm{c}}$ & $87.8^{\mathrm{NS}}$ & $45^{\mathrm{NS}}$ & $3.29^{\mathrm{bcd}}$ & $2.75^{\mathrm{bc}}$ \\
\hline IR64-Sub1 & P-DSS & $82.3^{\text {cd }}$ & $315^{\mathrm{ab}}$ & $1.08^{\mathrm{c}}$ & $85.5^{\mathrm{NS}}$ & $46^{\mathrm{NS}}$ & $3.25^{\mathrm{bcd}}$ & $2.74^{\mathrm{bc}}$ \\
\hline IR64-Sub1 & P-TP & $95.4^{\mathrm{ab}}$ & $223^{\mathrm{e}}$ & $1.45^{\mathrm{b}}$ & $83.1^{\mathrm{NS}}$ & $44^{\mathrm{NS}}$ & $3.51^{\mathrm{a}}$ & $2.77^{\mathrm{bc}}$ \\
\hline \multicolumn{2}{|c|}{ Mean } & $85.0^{A}$ & $266^{\mathrm{B}}$ & $1.18^{A}$ & $84.5^{\mathrm{A}}$ & $0.45^{\mathrm{A}}$ & $3.21^{\mathrm{A}}$ & $2.57^{\mathrm{B}}$ \\
\hline
\end{tabular}

NP, non-priming; NS, non-significant; DS-direct seeding without stagnation of water; DSS, direct seeding with $10 \mathrm{~cm}$ stagnation of water on soil surface; TP, transplanting of 25 days old seedlings; $\mathrm{P}$, priming with simple tap water. In a column the same small and upper case letter do not differ significantly. 


\section{CONCLUSION}

The study showed that proper management option could improve rice productivity under anaerobic direct seeding conditions. Coating with calcium peroxide though improved germination potential of rice under oxygen deficiency; the technique was not so popular outside Japan due to high cost of the chemical and tedious coating procedure (Ota, 1982). Seed treatment with $\mathrm{KNO}_{3}$ though beneficial- the impact of it was not so big as compared to seed soaking followed by sun drying. Seed soaking with water followed by sun drying found comparable with that of calcium peroxide coating under anaerobic seeding. Water priming found to be better not only under anaerobic seeding but also under normal direct seeding and transplanting. It showed that water priming was a good contingency measure to get assured yield under different methods of rice cultivation. The technique is simple, and all the resources are available at farmers' door. So, adoption of technique is possible. Rice cultivation under direct seeding is more secured by the adoption of water priming.

\section{ACKNOWLEDGEMENT}

Authors are grateful for financial support partly from the ICAR-National Rice Research Institute, Cuttack and partly from the National Initiative on Climate Resilient Agriculture project and Emeritus Scientist project (ICAR, New Delhi) to RKS.

\section{REFERENCES}

Dar, M.H., Janvry, A.D., Emerick, K., Raitzer, D., and Sadoulet, E. (2013). Flood-tolerant rice reduces yield variability and raises expected yield, differentially benefitting socially disadvantaged groups. Scientific Reports, 3, 1-8.

Das, K.K., Panda, D., Nagaraju, M., Sharma, S.G., and Sarkar, R.K. (2004). Antioxidant enzymes and aldehyde releasing capacity of rice cultivars (Oryza sativa L.) as determinants of anaerobic seedling establishment capacity. Bulgarian Journal of Plant Physiology, 30(1-2), 34-44.

Farooq, M., Basra, S.M.A., Ahmad, N., and Murtaza, G. (2009). Enhancing the performance of transplanted coarse rice by seedpriming. Paddy and Water Environment, 7(1), 55-63.

Farooq, M., Kadambo, H.M.S., Rehman, H., Aziz, T., Lee, D.J., and Wahid, A. (2011). Rice direct seeding: Experiences, challenges and opportunities. Soil and Tillage Research, 111(2), 87-98.

Ismail, A.M., Ella, E.S., Vergara, G.V., and Mackill, D.J. (2009). Mechanisms associated with tolerance for flooding during germination and early seedling growth in rice (Oryza sativa). Annales of Botany, 103(2), 197-209.

Mamun, M.A.A. (2014). Modelling rice-weed competition in direct-seeded rice cultivation. Agricultural Research, 3(4), 346-352.

Ota, Y. (1982). Promotion of emergence and establishment of rice seedlings by using calcium peroxide-coated seeds in direct sowing on flooded paddy field. Japanese Journal of Agricultural Research Quarterly, 15, 221-226. 
Panda, D., and Sarkar, R.K. (2012). Role of non-structural carbohydrate and its catabolism associated with SUB1 QTL in rice subjected to complete submergence. Experimental Agriculture, 48(4), 502-512.

Ray S., Vijayan, J., and Sarkar, R.K. (2016). Germination stage oxygen deficiency (GSOD): An emerging stress in the era of changing trends in climate and rice cultivation practice. Frontiers in Plant Science, 7, 671 doi: 10.3389/fpls.2016.00671.

Sarkar, R.K. (1998). Saccharide content and growth parameters in relation with flooding tolerance in rice. Biologia Plantarum, 40(4), 597-603.

Sarkar, R.K. (2012). Seed priming improves agronomic trait performance under flooding and non-flooding conditions in rice with QTL SUB1. Rice Science, 19(4), 286-294.

Sarkar, R.K., Bera, S.K., and De, R.N. (1999). Rice (Oryza sativa) cultivars for anaerobic seeding. Indian Journal of Agricultural Science, 69(7), 73-76.

Sarkar, R.K., and Das, S. (2003). Yield of rainfed lowland rice with medium water depth under anaerobic direct seeding and transplanting. Tropical Science, 43(4), 192-198.

Setter, T.L., Ramakrishnayya, G., Ram, P.C., and Singh, B.B. (1995). Environmental characteristics of floodwater in eastern India: relevance to flooding tolerance of rice. Indian Journal of Plant Physiology, 38(1), 34-40.

Vijayan, J., Senapati, S., Ray, S., Chakraborty, K., Ali M.K., Basak, N., Pradhan, B., Yeasmin, L., Chattopadhyay, K., and Sarkar, R.K. (2018). Transcriptomic and physiological studies identify cues for germination stage oxygen deficiency tolerance in rice. Environmental and Experimental Botany, 147, 234-248.

Yamauchi, M., and Choung, P.V. (1995). Rice seedling establishment as affected by cultivar, seed-coating with calcium peroxide and water level. Field Crops Research, 41(2), 124 136. 